\title{
A Simplified Working Classification Proposed for Myxoid Tumors of Oral Cavity
}

\author{
Manas Bajpai*, Nilesh Pardhe
}

- Department of Oral and Maxillofacial Pathology, NIMS Dental College, Jaipur, India

\begin{tabular}{|c|c|}
\hline \multicolumn{2}{|l|}{ Article Info } \\
\hline \multicolumn{2}{|l|}{ Received 25 Jul 2016; } \\
\hline \multicolumn{2}{|l|}{ Accepted 22 Nov 2016; } \\
\hline \multicolumn{2}{|l|}{ Published Online 01 Apr 2017; } \\
\hline \multicolumn{2}{|c|}{$\begin{array}{l}\text { Corresponding Information: Dr Manas Bajpai, Associate professor, Department of Oral and Maxillofacial Pathology, NIMS Dental College } \\
\text { Shobha Nagar, Jaipur (India), Email: dr.manasbajpai @ gmail.com }\end{array}$} \\
\hline $\begin{array}{l}\text { opyright } \odot \text { 2017, IRANIAN JOURNAL OF PATHOLOGY. This is an open- } \\
0 \text { International License which permits copy and redistribute the material just }\end{array}$ & $\begin{array}{l}\text { distributed under the terms of the Creative Commons Attribution-noncomr } \\
\text { nercial usages, provided the original work is properly cited. }\end{array}$ \\
\hline $\begin{array}{l}\text { Dear Editor-in-Chief } \\
\text { Myxoid tumors of the oral cavity encompass a } \\
\text { broad spectrum of lesions, primarily neoplastic } \\
\text { (1). Significant variations in the biological } \\
\text { behavior ranging from completely harmless to } \\
\text { malignant neoplasm require an accurate } \\
\text { histopathological diagnosis to ensure a proper }\end{array}$ & $\begin{array}{l}\text { between clinical and histopathological features of } \\
\text { these group of tumors, which often produces a } \\
\text { diagnostic difficulty to clinicians and oral } \\
\text { pathologists (3). There is no approved working } \\
\text { classification for myxoid tumors of the oral cavity } \\
\text { in the literature. A simple working classification of } \\
\text { myxoid tumors is proposed here (Table } 1 \text { ) }\end{array}$ \\
\hline
\end{tabular}

treatment (2). A considerable overlapexists

Table 1. A simple working classification for myxoid tumors of oral cavity

$\begin{array}{lll}\text { S NO CATEGORY TUMORS } & \text { TUPOR }\end{array}$

\begin{tabular}{|c|c|c|}
\hline 1 & Adipose tissue tumors & $\begin{array}{c}\text { Myxolipoma } \\
\text { Myxiliposarcoma }\end{array}$ \\
\hline 2 & Neural tumors & $\begin{array}{l}\text { Myxoid neurofibroma } \\
\text { Neurothakeoma } \\
\text { Malignant peripheral nerve } \\
\text { sheath tumor }\end{array}$ \\
\hline 3 & Fibroblastic tumors & $\begin{array}{l}\text { Myxofibroma } \\
\text { Nodular fasciitis } \\
\text { Myxofibrosarcoma }\end{array}$ \\
\hline 4 & Chondroblastic tumors & $\begin{array}{l}\text { Ectomesenchymal } \\
\text { chondromyxoid tumor } \\
\text { Myxoid chondrosarcoma }\end{array}$ \\
\hline 5 & Muscle tumors & Myxoid leiomyosarcoma \\
\hline 6 & Odontogenic tumors & Odontogenic myxoma \\
\hline 7 & Miscellaneous & $\begin{array}{l}\text { Soft tissue myxoma } \\
\text { Ossifying fibromyxoid tumor } \\
\text { Malignant ossifying } \\
\text { fibromyxoid tumor }\end{array}$ \\
\hline
\end{tabular}


This classification is based on the predominance of the areas of myxoid degeneration in histopathology of the tumors of oral cavity. This classification includes adipose, neural, fibroblastic, chondroblastic, muscle, odontogenic and miscellaneous tumors. This classification wouldprovide a better insight into the histopathology of myxoid tumors of oral cavity and wouldbe useful for oral pathologists and cytopathologists.

\section{References}

1. Graadt van Roggen JF, Hogendoorn PCW, Fletcher CDM. Myxoidtumours of soft tissue. Histopathology 1999;35:291

2. Za'mecnı'k M. Vascular myxolipoma (angiomyxolipoma) of subcutaneous tissue. Histopathol. 1999; 34(2):180-1.

3. FletcherCDM, UnniKK, MertensF (ed s.). World Health Organization Classification of Tumours. Pathology and Genetics of Tumours of Soft Tissue and Bone. Lyon: IARC Press; 2002

\section{How to Cite This Article:}

Bajpai, M., Pardhe, N. A Simplified Working Classification Proposed for Myxoid Tumors of Oral Cavity. Iran J Pathol, 2017; 12(4): 403-404. 